\title{
The Defense Policy of Czechoslovakia and the Czech Republic Since 1989: Stages, Milestones, Challenges, Priorities, and Lessons Learned
}

\section{Josef Prochazka *}

The end of the Cold War dramatically changed the perception of international security and the subsequent formulation of security and defense policies in both Western and Eastern bloc countries. The newly established political leadership in the formerly communist countries of Central and Eastern Europe had to struggle to adapt their defense policies to a new politico-strategic environment while dealing with the many challenges of democratic governance. Furthermore, the transformation of these states also required a transition from a centrally-planned economy to free market structures.

The Czechoslovak Federal Republic (CSFR)—known since 1 January 1993 (after its peaceful dissolution) as the Czech Republic (CR) — was no exception to this process. The CSFR's primary goal after the Velvet Revolution ${ }^{1}$ was to establish a liberal democracy and a free market economy in the light of Western political and economic values. ${ }^{2}$ Ensuring external and internal security has been always seen as an integral part of those overall objectives; thus, the key steps of the transition from communism in the Czech Republic were profoundly connected with security and defense policy formulation and its execution.

This essay examines the main drivers shaping the defense policy of the CSFR and CR since 1989. It also charts its evolution in the form of defense sector reforms. This project also identifies the most important lessons learned, which may be useful for future defense policy formulation and execution in small and medium-size countries that are undergoing the process of military transformation as an integral part of their overall democratization.

For the purpose of this project, "defense policy" is understood as a program for defending a country against its enemies and as a set of all necessary precautions taken by one state in order to safeguard and strengthen its external security. Defense policy is a process, with objectives and priorities. The political leadership of the CSFR and CR has always strived to adopt a liberal defense policy that reflects developments in the national and international security environment, national values and interests, and that

Josef Prochazka (LTC, ret.) has been responsible since 2007 for strategic planning within the Defense Policy and Strategy Division of the Czech Ministry of Defense. He previously served as the deputy director of the Institute for Strategic Studies at the Czech Defense University. He writes on strategic management, strategic planning, and the management of defense resources.

1 The so-called Velvet Revolution, by which Czechoslovakia shook off Communist rule, began on 17 November 1989 with student demonstrations in Prague.

2 Thomas Szayna and James Steinberg, Civil-Military Relations and National Security Thinking in Czechoslovakia: A Conference Report (Santa Monica, CA: RAND Corporation, 1992), 24. 
takes account of the resources available to small, rapidly developing countries. The central questions addressed in this essay are how successful was this process and what could have been accomplished more effectively?

The formulation and execution of defense policy in the CSFR and CR were more or less successful. One could consider the Czech Republic as a very successful country in this context. ${ }^{3}$ On the other hand, not all of the visions, strategies, and plans that were contemplated by the new Czech state became a reality, and there exists an excellent opportunity to analyze the causes behind these setbacks in order to share valuable experience and lessons learned.

This paper charts the development and execution of the defense policy of the CSFR and the $\mathrm{CR}$, and identifies four distinct periods in this almost twenty-year-long process:

- Democratization

- Integration

- Reforms

- Transformation.

Each of these periods was driven by different objectives, trends, and events. Furthermore, each period was reflected as the official defense policy of the Czech Republic in strategic and conceptual documents approved by the Czech Parliament.

\section{The Military in Czech Society}

\section{Starting Position}

No independent formulation and execution of defense policy existed during the Communist era in Czechoslovakia. The Czechoslovak People's Armed Forces (CPAF) were shaped - in their structure, equipment, doctrine, and support-according to Soviet offensive strategy. In comparison to the country's population, economy, and resources, the CPAF were relatively robust, heavily equipped, and supported by a substantial defense industry. The Czech military during this era was entirely controlled by the governing Communist Party; most generals and high-ranking officers were members of the Communist Party, and all officers were loyal to and active supporters of the totalitarian regime. The CSFR was a member of the Warsaw Pact and, since the 1968 invasion, Soviet armed forces operated on its territory. ${ }^{4}$ Forces under high operational readiness

3 The U.S. Secretary of Defense William Perry said in September 1995 on a visit to the Czech Republic that the country was leading Central Europe's race to join NATO, and that it had made more progress toward democracy than any other nation in the region. (Associated Press Worldstream, 19 September 1995.)

4 One of the new government's first acts was to suggest talks with Moscow on the future of the 80,000 Soviet soldiers that had been stationed in Czechoslovakia since the Warsaw Pact invasion that crushed the reforms of 1968. See "Czech Party Names New Government," St. Louis Post-Dispatch, 4 December 1989. 
were stationed along the nation's western border, while low-readiness forces, military schools, and supporting elements were located in the eastern part of the country. ${ }^{5}$

Czech society's opinion of the CPAF was very low, because these forces had been ineffective in repelling either the 1938 German invasion or the 1968 Soviet takeover. Furthermore, the CPAF were misused by the Communist regime to stop public demonstrations against the Warsaw Pact invasion in 1968 and the so-called "Normalization Process," which was initiated in August 1969.

\section{Democratization (1989-1992)}

The period of democratization in Czech society began on 17 November 1989. In this era, the nation's defense policy focused primarily on depoliticizing the CPAF by applying democratic control principles based on the Western democratic model. This objective was seen as a matter of urgency because the new political leadership saw the $\mathrm{CPAF}$ as a potential threat to the democratization process in society as a whole. ${ }^{6}$

This approach to defense policy was driven by the assumption that the danger of nuclear holocaust had disappeared. As a result of this assumption (and the anticipated peace dividend), the defense budget in the CSFR and other countries was reduced, along with their defense capability. Nevertheless, the new world proved to be a dangerous place, filled with new challenges. The dissolution of Yugoslavia and the Soviet Union demonstrated this fact and threatened the security and defense interests of the Czech Republic.

In November 1990, the Czech government approved The Concept for the Development of the Czechoslovak Army by the End of 1993, which outlined the relocation of units and called for massive reductions in personnel, weapon systems, and infrastructure. Additional restructuring included changes in the command and force structure. At the same time, a more defensive military strategy and doctrine for the CSFR had been adopted in March 1991. Czech defense policy during this period stressed the importance of independent territorial defense of the entire country against a non-specified opponent instead of its former anti-NATO orientation.

Concurrently, domestic defense industry research, development, and production potential and capabilities had been reduced through conservation of military production, restructuring, and privatization of state-owned factories. This process did not have a significant negative impact on the economic and social stability of the country (the Slovak part of the country was affected more seriously, due to its greater reliance

5 As of 31 December 1989, the CSPA's main combat force comprised fifteen ground divisions, two air force divisions, two air defense divisions, an artillery division, and a number of surface-to-air missile units. Some 210,000 personnel were on active duty, of whom 148,595 were conscripts and 61,405 were military professionals - 41,715 generals and other officers and 19,690 non-commissioned officers (NCOs). The CSPA also employed about 80,000 civilian staff.

6 Miroslav Tuma, Relics of Cold War Defense Transformation in the Czech Republic (Stockholm: International Peace Research Institute, Policy Paper No. 14, September 2006); available at http://books.sipri.org/files/PP/SIPRIPP14.pdf. 
on defense production). The critical issue of this period became the withdrawal of Soviet military forces to the Russian Federation. This objective was successfully completed - almost exactly in parallel to the dissolution of the Warsaw Pact Treaty - on 30 June $1991 .^{7}$

Unfortunately, due to historical resentments and the arrogance of both the Czech and Slovak political leadership, the unity of the CSFR became fragile after the revolution. The union of the two in the form of Czechoslovakia was peacefully dissolved on 31 December 1992. The military assets of the former state were divided between the Czech and Slovak Republics in a fair and pragmatic way, in proportion to their respective population (the ratio was approximately $2: 1$ ).

By the end of 1992, the democratization stage had been successfully completed. The armed forces were controlled by the civilian minister of defense, and had been completely depoliticized. The Communist political architecture in the ministry of defense was abolished. This ministry's structure was changed in the spring of 1991, and clear lines were drawn between civilian and military responsibilities. The discredited generals, officers, and members of the counter-intelligence service left the armed forces after several screening processes were conducted. More importantly, decisions about further development of the armed forces and their eventual operational use were to be made in accordance with the newly adopted constitution and respective laws by a democratically elected government. The position of an Inspector General, who was intended to oversee the armed forces, was created in December 1990. His duties included performing inspections and preparing parliamentary reports concerning defense policy and strategy implementation, defense spending, and the level of military preparedness. Most importantly, the armed forces remained politically neutral during the first years following the Velvet Revolution. This neutrality and loyalty to the new political leadership had a positive impact on the democratic development of the country and the peaceful dissolution of Czechoslovakia into its two successor republics.

The defense policy that was in place during this period reflected the need to display support for international peace and stability. This resulted in the deployment of a chemical unit as a part of a coalition force during Operation Desert Storm during the first Gulf War (1990-91) and in participation by one infantry battalion in UN peacekeeping operations in Bosnia and Herzegovina as a part of UNPROFOR in 1992. Both operations were successfully accomplished and contributed to gains in valuable operational experience within the Czech military. As a direct result of these deployments, the image of the armed forces in Czech society improved significantly.

7 Officials in Czechoslovakia wanted to replace both Cold War blocs (NATO and Warsaw Pact) with a pan-European collective security system based on the Conference on Security and Cooperation in Europe. They believed that this arrangement would overcome the EastWest dichotomy. They called for the withdrawal of U.S troops from Europe as well. They also considered Czechoslovak neutrality as an option (as reflected in Henry Kissinger's proposal in July 1990). See Szayna and Steinberg, Civil-Military Relations and National Security Thinking in Czechoslovakia, 26. 
The formulation of defense policy during this period was negatively influenced by the new political leadership's lack of expertise in security matters in general, and in defense in particular. It resulted in unrealistic assessments of future needs and the role of the armed forces. Due to these errors, questionable modernization programs were adopted during this era.

Obviously, after the massive defense budgets of the Communist era, the Czech military budget saw dramatic cutbacks. As a result of these reductions, research, development, and new procurement projects had to be more or less frozen. Furthermore, the armed forces were required to reduce their manpower and operational costs significantly. It accomplished this by decreasing staff, reducing training activities, and shortening the time for compulsory service from twenty-four to eighteen months.

\section{Integration (1993-1999)}

The process of integrating the Czech Republic into Western political and military structures started before the formal offer of NATO membership was extended in $1997 .{ }^{8}$ In September 1990 and in the spring of 1991, the NATO Secretary-General visited the CSFR, and Czech officials expressed their hope of one day joining NATO, which was neither politically nor militarily prepared for enlargement at this time.

The execution of defense policy in the Czech Republic was still influenced by the reductions in the Treaty on Conventional Armed Forces in Europe and by the ongoing tensions in the Balkans (the conflict in Bosnia and Herzegovina, which started in 1995, and in Kosovo, which began in 1999). These conflicts seriously threatened security and stability not only in the general European region, but in the Czech Republic as well. These conflicts proved that future challenges would require a strong military. Furthermore, international solutions were required that were far superior to the capabilities of the UN-led peacekeeping force. The spectrum of threats and risks to the security of the Czech Republic were widening during this period, leading to an increased emphasis on the need for security cooperation and collective action instead of independent defense arrangements. A large, conventional attack against the Czech Republic was considered unlikely, but various smaller threats were proliferating.

Based on this development, the strategic objectives of Czech defense policy in this integration stage were clearly defined. After initial political discussions concerning future territorial defense requirements, the country's geostrategic position in Europe, its economic possibilities, resource limitations, and possible future security and defense interests, the Czech Republic determined to pursue NATO membership and support the broad-ranging effort to strengthen relations with the West. These efforts were not restricted to the armed forces, but also included the realms of politics and economics. As a matter of fact, this objective enjoyed both public and political support across the entire political spectrum and resulted in enhanced interest on the part of the

8 "Protocol to the North Atlantic Treaty on the Accession of the Czech Republic," available at www.army.cz/images/id_8001_9000/8344/3.doc. 
political leadership in the country's future security and defense needs. ${ }^{9}$ Persistent and vocal opposition from Russia was viewed as the most serious obstacle to this integration process. ${ }^{10}$

During this seven-year integration stage, there were several important strategic and conceptual documents that were elaborated by the ministry of defense and adopted by the Czech government, which will be discussed below. The first important step taken was that the position of the minister of defense was significantly altered. Unfortunately, there had been four ministers of defense between 1993 and 1999, each with different ideas concerning how the defense sector should be reformed. ${ }^{11}$

Another challenge that had to be confronted was the fact that there was still a very limited ability within the ministry of defense and the armed forces to think strategically and conceptually, despite efforts by Western countries to educate defense sector personnel and to provide some kind of expertise. The first tangible result in the process of Western integration was achieved when the Czech Republic was admitted to the North Atlantic Cooperation Council on 1 January 1993. In the wake of this step, the Czech Republic joined the NATO Partnership for Peace on 10 March 1994, and then signed an associated partnership agreement with the Western European Union on 9 May 1994.

Between 1993 and 1997, the Czech defense budget did not allow for a qualitative change in the armed forces in terms of modernization of equipment, conduct of needed training, and improvement of working conditions. ${ }^{12}$ As a result, two separate and distinct forces were being created. The Rapid Reaction Forces were high-priority forces, designed to be deployable and interoperable with troops from other NATO allies. The Territorial Forces were lower priority forces responsible mainly for territorial defense. ${ }^{13}$ Furthermore, in an effort to cut operational costs, the Air Force retired 20 percent of its equipment. Other steps that were taken included reducing the command

9 When the Czech Republic became a member of NATO, 66.9 percent of the population supported accession to membership, while 22.6 percent opposed it, and 10.5 percent held no opinion. Even more interesting fact was that 80 percent of the armed forces' professional soldiers supported entry into NATO. See Jeffrey Simon, NATO and the Czech and Slovak Republic, A Comparative Study in Civil-Military Relations (Lanham, MD: Rowan and Littlefield Publishers, 2004), 79.

${ }^{10}$ The Security Policy of the Czech Republic (Prague: Institute of International Relations, 1997), 17.

11 Jeri Sedivy, "Czech Military Transformation," NATO Review (Spring 2005); available at www.nato.int/docu/review/2005/issue1/english/analysis.html.

As the Czech Republic's first minister of defense, Antonym Bauds, noted in 1993, the Communist-inspired symbols that decorated the main meeting room of the ministry of defense could be easily removed, but it was much more difficult to transform the Czech armed forces into a modern military of the Western type. See Czech National News Wire (26 January 1993).

13 In the early 1990s, territorial defense still played an important role in Czech defense policy. See the Resolution of the Government of the Czech Republic of 9 June 1993 (No. 297) on the negotiation of the Concept for the Development of the Army of the Czech Republic by 1996; available at http://racek.vlada.cz/usneseni. 
structure from six to three levels, ${ }^{14}$ cutting the length of compulsory service from eighteen to twelve months, and adopting the concept of semi-professional armed forces. ${ }^{15}$ Mobilization measures, reserves, and defense industry capability were still seen as essential components of defense policy, but they drained significant resources from the military budget.

Defense concepts adopted in 1997 and 1999 reflected NATO requirements, and were oriented toward the long term. ${ }^{16}$ However, successful implementation of these concepts was compromised by inadequate and poorly managed resources. This unsystematic approach resulted in a loss of prospective personnel, who were not motivated enough to stay in this unstable environment - characterized by low salaries, limited career opportunities, mismanagement, an eroding organizational culture, and ineffective military budgeting, acquisition, and procurement processes.

Before the Czech Republic joined NATO on 12 March 1999, the Czech armed forces had fulfilled the military requirements for membership. Through this process, secure and interoperable communication and exchange of information were ensured, airfield infrastructures were modernized, and necessary logistical arrangements for possible NATO reinforcement on Czech territory were established.

Security and defense issues had never played a substantial role in Czech domestic policy up to this point. However, the decision to strive for NATO membership represented a turning point in this situation during the second half of the 1990s. The NATO accession process quickened all of the defense sector reform processes. Military legislation was drafted and approved by Parliament in 1998 and 1999, and the government approved basic security documents in $1999 .{ }^{17}$

We can argue, however, that Czech defense policy in this integration period neither succeeded in focusing on the qualitative characteristics of the defense sector, nor did it properly address the need for stable and sustainable development that would realistically reflect potential risks and take advantage of upcoming opportunities (such as those offered by NATO membership). Despite many problems with reform implementation - e.g., inappropriate decision making, irresponsible management of financial and human resources, a lack of long-term planning, ineffective acquisition, excessive logistic support structures, poorly maintained and unwieldy infrastructure, and useless stocks of old materiel and ammunition - the use of military capabilities actually be-

${ }^{14}$ Simon, NATO and the Czech and Slovak Republic, 29.

15 Resolution of the Government of the Czech Republic of 21 December 1995 (No. 732) on the Military Strategy of the Czech Republic; available at http://racek.vlada.cz/usneseni.

16 Resolution of the Government of the Czech Republic of 26 March 1997 (No. 178) on the Plan of the Concept for the Development of the Army of the Czech Republic until 2000 with an Outlook to 2005; available at http://racek.vlada.cz/usneseni/. See also "The Concept for the Development of the Defense Establishment until 2004 with Outlook to 2009," Vojenské rozhledy 4 (1999): 3-15; available at www.army.cz/avis/vojenske rozhledy/499.htm.

17 Marie Vlachova, Reform of the Armed Forces of the Czech Republic: A Success or a Failure (Geneva: Geneva Centre for the Democratic Control of Armed Forces, Working Paper Series, No. 78, August 2002). 
came one of the Czech Republic's success stories. First, during a period of severe floods in Moravia 1997, the Czech armed forces proved to be the only effective organization able to protect life and property. Second, successful deployments of Czech units in NATO-led operations in the Balkans proved the growing interoperability with the Allies of some Czech military assets on the operational and tactical level. For example, the NATO Integrated Air Defense System ensured protection of Czech airspace, with contributions from the Czech Republic of appropriate command and weapon systems and sensors.

Nevertheless, political decision making concerning deployments abroad was highly controversial, because of the lack of any common interest and consensus among political parties. Despite the economic recession and political instability in 1997, the Czech government pursued a strict fiscal policy. The ministry of defense therefore experienced (contrary to the case in the first half of the 1990s) a positive budgetary development between 1999 and 2002. Military expenditures became one of the government's priorities. The government decided to incrementally increase the share of military expenditures as a percentage of GDP by 0.1 percent annually, with a goal of reaching 2 percent of GDP by the year $2000 .^{18}$

This decision demonstrated the willingness of the Czech political leadership to share the defense burden with Allies, and showed its determination to continue with the reforms necessary to achieve full interoperability. This approach also enabled an ambitious modernization program designed to improve military operational capability and support an ailing domestic defense industry.

\section{Reforms (2000-2006)}

After two years in NATO, the Czech Republic had successfully implemented only 26 of its 132 force goals. ${ }^{19}$ This resulted in sharp criticism from NATO which, coupled with the disappointing results from the military campaign in Kosovo, pushed both Czech politicians and military representatives to reevaluate the achievements of the past decade and to examine the country's options for choosing the reform process that could best produce a more effective and relevant military. ${ }^{20}$ It was determined that the reform process that would be most likely to succeed was one that would take advantage of NATO membership. Unfortunately for the defense sector, however, the government's top priority became EU membership.

Defense policy formulation was influenced by a growing number of intra-state conflicts (failing states) and unprecedented terrorist activities by radical Islamic groups (such as the attacks of September 11). The probability of a conventional attack against the Czech Republic was assessed as very low. Furthermore, the potential to predict a conventional attack in advance and take the appropriate measures to enhance the nation's defense capabilities was considered to be relatively feasible. In response to these

18 Program statement of the Government of the Czech Republic, 23 July 1996; available at http://wtd.vlada.cz/scripts/detail.php?id=501.

19 Simon, NATO and the Czech and Slovak Republic, 104.

20 The Czech Republic conducted its Strategic Defense Review in 2001. 
emerging threats, Czech defense policy was adapted again, and addressed the new requirements for enhancing the military posture and capabilities of the nation's armed forces.

The objective of this stage was to reform a still inflated military into a small force with 35,000 active soldiers and 10,000 civilian employees. Furthermore, an ambitious modernization program was developed, spanning the entire Czech military, including infantry, air defense, combat service and combat service support, and the infrastructure of large military bases. Stress was put on deployability, mobility, and interoperability with NATO forces. Human resources received the highest priority, with an emphasis on career opportunities, fair evaluation and promotion procedures, improved benefits, and better working conditions. Discussions involved the creation of an all-volunteer professional force, and the termination of conscription. As necessary preconditions for this reform, several key steps were deemed necessary: the rationalization of all business processes, the reduction of garrisons, changes in the command and force structure, and the reduction of reserve forces. It was believed that by implementing the outlined measures, the ministry of defense could free up resources desperately needed for the further modernization of obsolete weaponry, materiel, and infrastructure and for improving the working and social conditions of military and civilian personal. Emphasis was placed on "soft" values, such as pride, the military's standing in society, and the overall cultural and professional improvement of the military organization. ${ }^{21}$

During this reform period, existing strategic documents were updated-namely the Security Strategies of 2001 and 2003, and the Military Strategies developed in 2002 and 2004. These amended documents reflected the rapidly changing security environment, the requirement for a complex approach to security and defense, an evolution in NATO's political and military thinking, and the Czech Republic's international obligations and economic realities. Based on the basic principles of these strategic documents, two conceptual documents for further development of the armed forces were adopted by the government. ${ }^{22}$ The original Concept 2002 was deemed too ambitious and expensive. This became even more obvious after adjustments were made to account for new financial realities in 2003. Significant reductions were needed to bring this concept in balance with the resources available - specifically, a force reduction from three to two mechanized brigades, a reduction of operational commands from five to two, garrison realignment, and a reduction in personnel (target numbers cut by 9,000 military staff, to 26,200 and by 1,200 civilian staff, to 8,800 ). The government was

21 "Concept for the Development of a Professional Army of the Czech Republic and Mobilization of Armed Forces," Vojenské rozhledy 3 (2002); available at www.army.cz/avis/ vojenske_rozhledy/2002_3/obsah3.htm.

22 "Concept for the Development of a Professional Army of the Czech Republic and Mobilization of the Czech Armed for the Period 2004-2008" and "Concept for the Development of a Professional Army of the Czech Republic and Mobilization of the Czech Armed Forces Revised for the New Resource Framework for period 2004-2010," A-Report 24 (2003); available at www.army.cz/avis/areport2003/ar24str.pdf. 
also forced to lower its sights in terms of deployable capability (a deployable brigade was downsized from 5,000 to 3,000 troops).

During this period, the Czech Republic successfully accomplished its strategic objective of integration into Western structures, and became a full member of the EU on 1 May 2004. The Czech military became an all-volunteer force on 1 January 2005, faster than had been foreseen in the conceptual documents. ${ }^{23}$ Furthermore, the armed forces reached its initial operational capability at the end of 2006 as planned in the first step of its reform process (thirty-seven units fulfilled NATO standards to create a brigade task force of up to 3,000 troops prepared for NATO deployment). The Czech command and force structure was modified according to the revised concept document. ${ }^{24}$ Personnel resources were stabilized, with salaries being increased, along with improvements to the career management process and changes to the personnel structure. $^{25}$ The number of garrisons, infrastructure, and stockpiles of materiel were reduced and rationalized. Specialization of the armed forces into units focusing on CBRN defense, Passive Surveillance Systems (PSS), and medical service became an investment priority. The military education system was adjusted to account for the declining demand for officers by the smaller military. Outsourcing of services was implemented to ensure that the functions previously conducted by conscripts continued to be accomplished. The most important (and the most controversial) modernization projects were accomplished-e.g., battle tanks, supersonic and subsonic aircraft systems, transport aircraft, and infrastructure. The armed forces successfully participated in foreign operations in the Balkans, Afghanistan, and Iraq. Success in defense reform was ineluctably connected to the Czech Republic's assuming greater responsibility and a more important role in multinational operations. In 2005, the Czech Republic became a lead nation in the Multinational Brigade in Kosovo and assumed its command. In 2006, the Czech Republic took responsibility for air traffic control at the Kabul International Airfield in Afghanistan. In addition, classical infantry units with broad-spectrum niche ca-

23 The Defense Concept from 1999 prescribed a gradual reduction in the number of conscripts as the Czech armed forces moved further towards professionalization. By 2009, the rapid reaction units should all be fully professional and there should be only around 22,000 conscripts on active duty. The Defense Concept from 2002 aimed to achieve an all-volunteer force by 2006 .

24 The main structure of the Czech military that was implemented in line with the revised Concept is as follows: an integrated $\mathrm{MoD}$ with directly subordinated elements (intelligence service, military police, special forces, military schools and hospitals) and two operational HQs. Joint Command consists of two mechanized brigades; an artillery brigade; a surveillance battalion; fixed-wing, rotary, and transport air bases; an air defense brigade; an air command and control brigade; a CBRN brigade; a logistic brigade; a rescue and engineer brigade; a communication battalion; a passive surveillance battalion; and a PSY OPS/CIMIC Centre. Supporting and training command is created by directorates for personal, logistic and medical support and training and doctrine.

25 Including the introduction of accommodation allowances, which were equal to approximately one-third of an officer's average pre-tax salary. 
pabilities were being used (medical, EOD, CBRN, military police, special forces, and helicopters).

During this stage of the defense reform process, the military budget again declined significantly as a result of changing government priorities after the short period of stability experienced in 1999. The first budget cut was connected with the floods during the summer of 2002. These cuts were necessary in order to pay for the reconstruction of destroyed national infrastructure. Later reductions in 2005 and 2006 were influenced by a strict government fiscal policy as the country pursued EU membership and worked to fulfill Stability Pact criteria to achieve admission into the EU Monetary Zone (the priority was the reduction of state debt and the budget deficit). ${ }^{26}$

\section{Transformation (2007-2025)}

During the transformation period, which is presently under way, Czech defense policy primarily addresses itself to the new strategic thinking in NATO, which is the product of a new perception of the security environment, taking into account such factors as the stability and reconstruction of failing states, the proliferation of WMD, ballistic missile defense, cyber defense, and energy security. Czech defense policy is also being driven by the demand to develop a more expeditionary military capability. ${ }^{27}$ Furthermore, during this period the newly elected government (a coalition government led by the Liberal Party) changed its attitude toward public spending, placing greater emphasis on saving and budget cuts.

As a result of these influences, in the first half of 2007 the MoD assessed its reform achievements concerning Concept 2002 and the revised Concept (2003). In addition, the MoD asked NATO for out-of-cycle consultation in order to deal with the growing gap between the financial resources required for further defense transformation and the resources allocated by the new Czech government. Based on this feedback, the government tasked the minister of defense to come up with feasible and realistic proposals in order to reestablish the equilibrium between the main objectives of the nation's defense policy and the available resources without compromising the Czech Republic's security or international obligations.

During this process it was recognized that the nation's military capabilities still did not completely meet rapidly changing military requirements. Defense planning disciplines were not adequately interconnected. There was still no effective command and control system within the ministry of defense or the armed forces, despite its reduced

${ }^{26}$ Those cuts created a gap greater than the amount of an entire year's military budget in the middle-term perspective in comparison with the money required for successful Concept implementation.

27 North Atlantic Treaty Organization, Comprehensive Political Guidance, endorsed by NATO Heads of State and Government on 29 November 2006; available at www.nato.int/docu/ basictxt/b061129e.html. 
size and improved efficiency. ${ }^{28}$ There were significant delays in some modernization projects (e.g., communications and information systems, armored personnel carriers, air and land transport), as well as in eliminating useless materiel and infrastructure. An effective corps of non-commissioned officers was also notably absent. The military's rank structure was still not properly balanced, featuring too many high-ranking officers. Furthermore, there were many civilian employees who lacked clear rules and procedures career progression.

Based on these deficiencies, the government recognized the need to build a more useful military with expeditionary capabilities that could serve worldwide, under diverse conditions, together with Allies and Partners, to accomplish peacekeeping missions in accordance with international law or to defend the Czech Republic and the security interests of its Allies and Partners. The conceptual framework outlined necessary changes in the ministry of defense and the armed forces up to 2018, when the Final Operational Capability (FOC) is to be achieved. Furthermore, the government asked the minister of defense to elaborate upon a more visionary outlook extending as far as $2025,{ }^{29}$ to update the Military Strategy of the Czech Republic, to rewrite the Concept for Armed Forces Mobilization, and to elaborate upon the Concept for the Protection of Czech airspace after 2015.

In the autumn of 2007, a transformation document was adopted by the government and discussed in parliament. In order to simultaneously meet new military requirements and comply with rapidly declining financial resources, political-military ambitions were adjusted in favor of supporting the most likely operational deployments. ${ }^{30}$ In line with this document, the command and force structure will be changed in order to deal successfully with the most likely operational scenarios. ${ }^{31}$ Business processes will be streamlined based on external audit results; spending for operation and maintenance will be more strictly monitored; investments in new materiel will be reprioritized; multinational cooperation in capability development will be enhanced; and strategic capabilities will be shared within NATO and the EU. It has become clear that most of the planned programs will be postponed and reduced (the armored personnel carrier program will be reduced by half), and that plans for large-scale infrastructure projects to concentrate units in garrisons will be disregarded. New programs aimed at supporting

${ }^{28}$ One of the reasons why command and control systems were not delivering desired output was the failure in the implementation of the process management model that has been seen as the most effective tool for overall business rationalization within the ministry of defense.

Long-Term Vision of the Czech Republic Ministry of Defense (Prague: Ministry of Defense, 2008); available at www.army.cz/images/id_8001_9000/8492/Dlouhodob_vize_resortu Ministerstva_obrany.pdf.

30 The Czech Republic is able to deploy 40 percent and sustain in operations 8 percent of its army, as is set forth in the Istanbul criteria, and plans to increase these figures up to 60 percent and 12 percent respectively by 2014 . Furthermore, all deployable units should meet NATO standards in line with the Capability Statements by 2018.

31 Preparations for worst-case scenarios-including mobilization, the maintenance of duplicate administrative structures and supporting databases of personnel and materiel, and training of reserves - will be reduced to a minimum. 
ongoing operations will be implemented or will receive higher priority, such as the modernization of the military's helicopters and the development of a new generation of UAVs, small personnel carriers, transport airplanes, communications and information systems and network-enabled capabilities).

During the summer of 2008, the government approved updating the Military Strategy to take into account the long-term vision for the transformation of the Czech armed forces. The Military Strategy set forth the nation's political-military ambitions and provided the basic principles for the construction and deployment of the armed forces. ${ }^{32}$ This document stressed the importance of collective defense and multinational cooperation for defending the Czech Republic. The military will most likely be deployed in full-spectrum joint, combined, and multinational operations. The nation will build one set of forces to operate with all international organizations, which will rely on sharing some strategic capabilities with Allies. ${ }^{33}$ The Czech armed forces will be modular, interoperable, and capable of cooperating with a wide spectrum of actors. Furthermore, the armed forces will provide niche capabilities in the field of CBRN protection and will be structured and equipped for the most likely operational scenarios. The ability to react to the most dangerous threats as the situation dictates will also not be ignored.

The Long-Term Vision is the first attempt since 1989 to look beyond the current security horizon and orient the MoD's administration and military planners toward long-term developments for both the ministry and the armed forces. One of the most important and remarkable successes during this period is indisputably the change in the way the Czech Republic's political leadership and military representatives have approached defense policy formulation and its implementation. After a long period of short-term and middle-term approaches, the nation has recognized the critical need for long-term strategic thinking. Long-term political guidance makes it easier for military planners to think about future military operations and required capabilities. Furthermore, armament and acquisition policy and human resource development policy benefit from this approach.

The MoD accelerated the implementation of transformation objectives in 2008 . Ministerial guidance consisting of six strategic objectives and tasks has been adopted, and the Middle-Term Plan (2009-2014) outlines programs and activities in order to meet those objectives and tasks in accordance with new priorities. The Czech Republic's obligations with respect to the NATO defense planning cycle for 2008-2018 were discussed and agreed to as challenging but fair. NATO's response to the Czech Defense Planning Questionnaire was the most positive since the Czech Republic entered NATO.

32 Resolution of the Government of the Czech Republic No. 908, on Military Strategy of Czech Republic (23 July 2008); available at www.army.cz/images/id_8001_9000/8492/Vojensk strategie_R-2008.pdf.

33 Strategic lift, strategic intelligence, air-ground surveillance, missile defense, protection of its air space within the NATO Integrated Air Defense System. 
Concerning the deployment of military capabilities, the Czech Republic will continue contributing in line with its updated political-military ambitions. During the second half of 2009, the nation will provide forces to the stand-by EU Battle Group. Furthermore, Czech supersonic aircraft will conduct air-policing missions in the Baltic countries in order to protect their airspace. The activities of the Provincial Reconstruction Team (PRT) in Afghanistan will support NATO stabilization and reconstruction efforts there, and helicopter deployments will enhance weak NATO intra-theater lift capabilities.

After analyzing the military budget, one can see that Czech defense spending is well below the agreed upon NATO benchmark in terms of percentage of overall GDP (the budget forecast for 2009 is for military spending of 1.4 percent of GDP). On the other hand, a reasonable balance between personnel ( 50 percent), operations ( 25 percent), and investment ( 25 percent) spending has been achieved. Additionally, the government pledged to cover costs of unplanned military deployments in case of crisis management.

\section{Lessons Learned}

Caution is always needed when identifying lessons learned and making recommendations for the future, or when highlighting mistakes for other countries to avoid. However, several aspects of the process of defense policy formulation and execution in the CSFR and the Czech Republic are worth considering for countries currently in a state of transition, whether they are NATO applicants or countries that are newly independent, newly democratic, or turning their attention to new military and non-military threats.

1. Strive for clear role delineation between political leadership and military representation. The principle of civil control over the military must be legally established and implemented by an educated, well-prepared, and responsible political leadership. (Successfully achieved)

2. The formulation of defense policy is easier than its implementation. The elaboration of realistic and feasible strategic and conceptual documents is difficult, but their implementation is even more complicated. People responsible for the design of defense reforms should be accountable for their implementation. (Still a desired goal)

3. Take a complex approach to security matters and promote a wide articulation of defense policy objectives. The main objectives of defense policy should be well balanced with policies of other areas of government, in order to gain needed political support for their implementation and to avoid significant budgetary constraints during the process. Plans and programs should convince the political leadership that they provide value for the money they will cost. Furthermore, defense policy execution should be reinforced by effective diplomacy; in the Czech case this included the withdrawal of Soviet Union military units, the dissolution of the Warsaw Pact, the dismemberment 
of the CSFR, and the Czech Republic's integration into Western structures. The reduction of the size of the military should be coupled with social programs and effective economic reforms including conversion, privatization, and restructuring of the defense industry. (Partially implemented)

4. Set acquisition policy objectives and modernization priorities. An acquisition policy must reflect overarching political goals, actual military needs, and the nation's level of technological development. Furthermore, it must strive for the most effective life-cycle cost solution. Acquisition of costly modernization programs should be the least-preferred solution for capability enhancement. Nonmaterial solutions involving business processes and improved tactics, techniques, and procedures should be given top priority. Project management should be performed in a timely manner, within both budget and delivery capabilities. (Partially applied)

5. Personnel management is critical. Investment in people should be given a high priority. Steps that should be taken include recruitment from competing markets using a set of incentives in line with demographic trends, selection of the best suited personnel, proper training reflecting the likely deployment realities, appropriate education, protection during operations, fair career opportunities, transparent promotion procedures, benefits based on fulfillment of standardized performance criteria and in balance with responsibilities, motivational working conditions, and social appreciation. (Striving for, but failed to achieve fully)

6. Allocations of financial resources reflect defense priorities. Limited resources require allocation based on transparently established priorities, defense policy objectives, and constantly updated financial standards. Furthermore, personnel expenditures, operational expenditures, and investment expenditures must be well-balanced, support the long-term objectives of defense policy, ensure adequate training, sustain demand for operational deployments abroad, and continue necessary modernization. Limited resources should be balanced with rational business processes within the entire $\mathrm{MoD}$ (new procedures, integration of information systems, outsourcing, and flexible organization). (Partially implemented)

7. Engage in strategic management and long-term defense planning. Decisionmaking processes at the strategic level must be supported by adequate analytical tools to enhance transparency and to avoid non-systematic solutions, misallocation of funds, and risks to the country's defense capability. Defense planning must be driven by rigorous analytical processes in order to determine long-term military operational requirements and must be adequately responsive to lessons learned during current operations (urgent operational requirements should not supersede the standard planning process). Internationally, the military should contribute its fair share to collective defense, shared capabilities, and cooperation. (Partially applied) 


\section{Conclusions}

The Czech Republic's process of defense policy formulation has always been seen as an integral part of security policy articulation within the nation, and is balanced with foreign, internal security, and economic policies. Economic interests have in many instances superseded defense interests (including procurement decisions, offset policies, and garrison and military infrastructure closures). To some extent, Czech defense policy has reflected changes in the internal and external security environment and public sentiment (democratization, integration, and professionalization). The objective of Czech defense policy has been mostly influenced by liberal values and beliefs. Processes such as the democratization of military structures, participation in international institutions, weapons nonproliferation and reduction, military diplomacy and cooperation, and conflict prevention have become the major drivers of defense policy in the Czech Republic, rather than an emphasis on strong military capabilities. The use of military power has always been seen as the option of last resort in solving security problems and crises, and this use of power has required an international mandate.

As reflected in this essay, the four periods of defense policy formulation and execution (democratization, integration, reform, and transformation) in the Czech Republic have resulted in an overall transformation of the country's defense sector. It has been an enormous task with many setbacks; however, almost two decades after the end of the Cold War, the defense interests of the Czech Republic are now safeguarded by membership in Western political, military, and economic structures (collective defense and a strong North Atlantic link) and by existing credible military capabilities which create a basis for fair and valuable contributions to both these structures and to international peace and stability operations.

Since 1989, the Czech military has been incrementally changed in many aspects to become an effective tool for defense policy execution. First, the Czech armed forces democratized in line with the Western model of democratic control of the military. Furthermore, the military was never used to resist or obstruct the broader transformation efforts underway in Czech society.

Third, the relics of the Cold War's robust forces - in terms of personnel, weaponry, and a military infrastructure with an immense mobilization capability and enormous industrial potential - have been replaced through painful, nonsystematic reforms which fortunately did not lead to social or economic disruption. To the contrary, these reforms have led to a flattened command structure and a deployable, sustainable, and fully professional force structure. Modernization of the Czech Republic's military has resulted from a combination of high-tech updates to outdated equipment and infrastructure. The speed of replacement and reconstruction depends on available resources. This process will continue in line with newly adopted strategic and conceptual documents and with the resources available.

Fourth, the Czech military has accelerated a process of successful integration into Western security structures, and has contributed significantly to enhancing the country's strong international recognition through successful operational engagements. Finally, the military's learning processes have been positively influenced by cooperation 
with Allies and Partners. Future long-term transformation has been contemplated to ensure continuous adaptation to the changing environment and new challenges.

A lot has been achieved in the last twenty years, and even more will be necessary to continue with the successful adaptations of the country's defense policy for the twentyfirst century. This will remain one of the most significant challenges confronting the Czech Republic. How it addresses this challenge will have profound and far-reaching implications for the nation's ability to protect and advance its vital strategic, security, and defense interests. 


\section{Bibliography}

Concept for the Development of a Professional Army of the Czech Republic and Mobilization of Armed Forces. Vojenské rozhledy 3 (2002).

Concept for the Development of a Professional Army of the Czech Republic and Mobilization of the Czech Armed Forces Revised for the New Resource Framework for period 2004-2010 In A-Report., 2003.

Czech Party Names New Government. St. Louis Post-Dispatch (1989).

Long-Term Vision of the Czech Republic Ministry of Defense. Prague: Ministry of Defense, 2008.

North Atlantic Treaty Organization, Comprehensive Political Guidance In NATO Heads of State and Government., 2006.

Program statement of the Government of the Czech Republic., 1996.

Protocol to the North Atlantic Treaty on the Accession of the Czech Republic. Brussels, 1997.

Resolution of the Government of the Czech Republic In Military Strategy of Czech Republic., 2008.

Resolution of the Government of the Czech Republic of 21 December 1995 In Military Strategy of the Czech Republic., 1995.

Resolution of the Government of the Czech Republic of 26 March 1997 In Plan of the Concept for the Development of the Army of the Czech Republic until 2000 with an Outlook to 2005., 1997.

Resolution of the Government of the Czech Republic of 9 June 1993 In negotiation of the Concept for the Development of the Army of the Czech Republic by 1996., 1993.

Sedivy, Jeri. "Czech Military Transformation." NATO Review (2005).

Simon, Jeffrey. NATO and the Czech and Slovak Republic, A Comparative Study in Civil-Military Relations. Lanham, MD: Rowan and Littlefield Publishers, 2004.

Szayna, Thomas, and James Steinberg. Civil-Military Relations and National Security Thinking in Czechoslovakia: A Conference Report. Santa Monica, CA: RAND Corporation, 1992.

The Concept for the Development of the Defense Establishment until 2004 with Outlook to 2009. Vojenské rozhledy 4 (1999): 3-15.

The Security Policy of the Czech Republic. Prague: Institute of International Relations, 1997.

Tuma, Miroslav. Relics of Cold War Defense Transformation in the Czech Republic In Policy Paper. Stockholm: International Peace Research Institute, 2006. 
SPRING 2009

Vlachová, Marie. Reform of the Armed Forces of the Czech Republic: A Success or a Failure In Working Paper Series. Geneva: Geneva Centre for the Democratic Control of Armed Forces, 2002. 